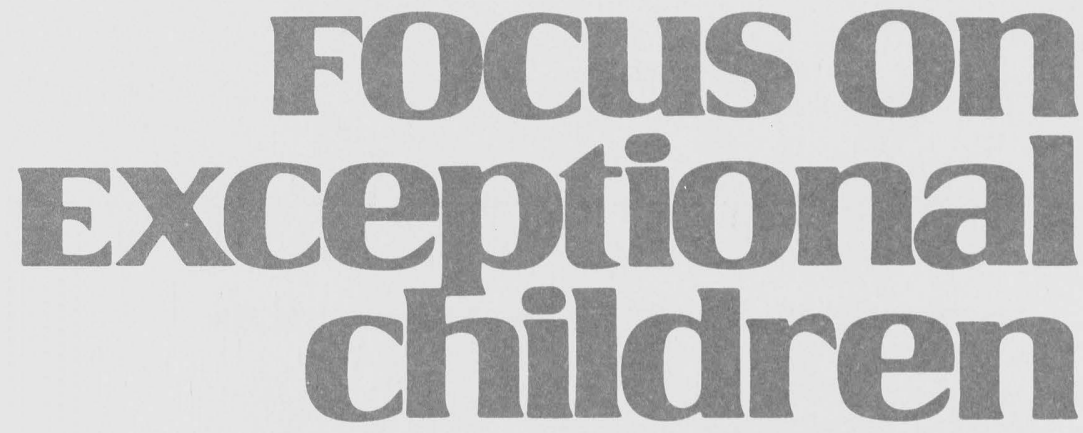

\title{
School Reform and Adolescents with Behavior Disorders
}

\author{
Peter E. Leone, Margaret J. McLaughlin, and Sheri M. Meisel
}

\begin{abstract}
I do not know if things will get better if there is change, but I do know that if things are to get better there must be change.

Anonymous
\end{abstract}

Adolescents with behavior disorders are the least successful students in our public schools. A number of studies indicates that of students enrolled in special education, those identified as having an emotional or behavioral disorder have one of the lowest rates of promotion and the highest rate of dropout and exit prior to graduation (U. S. Department of Education, 1991b). Further, only children identified as multiply handicapped or deaf-blind are educated in more restrictive settings than students with emotional or behavioral disorders (U. S. Department of Education, 1991b).

Within the past 10 years a number of national commissions, reports, and studies have recommended changes in the public school system in the United States. The recommendations range from an overhaul of the curriculum to reorganization of the manner in which schools deliver services to students and the ways in which decisions are made. In their blueprints for reform, many of the commissions, reports, and studies have all but ignored groups such as special and compensatory education ("America 2000" Choice Plan, 1991). The needs of students with emotional or behavioral disorders such as Jordi, Lisa, and David, in a biographical account by that title (Rubin, 1962), as well as ethnic or racial minorities such as the Boyz 'N the Hood (Nicolaides \& Singleton, 1991), have largely been overlooked. A few groups, however, have examined the effect of school reform proposals and pilot restructuring efforts on special populations.

Here, we examine school restructuring, the national education goals, and opportunities to improve the quality of education for adolescents with behavioral disorders. Much of the discussion involves analysis of reform proposals, with an assumption that changes in school structure have very real implications for students with emotional or behavioral disorders and the programs that serve them.

Peter Leone, Margaret McLaughlin, and Sheri Meisel are all affiliated with the Department of Special Education, University of Maryland, College Park. 


\section{NATIONAL LONGITUDINAL TRANSITION STUDY}

The National Longitudinal Transition Study (NLTS) of Special Education Students (Wagner, 1991) sheds light on the school experiences and outcomes of students with various disabling conditions. The study, based on a nationally representative sample of more than 8,000 students, synthesized information on students' characteristics, school careers, and post-secondary education or employment.

Data suggest that of secondary school students with disabilities aged 13-21 during the 1985-86 school year, the highest percentage receiving failing grades and the lowest percentage promoted were identified as emotionally disturbed. With regard to leaving school, $55 \%$ of the secondary school youths identified as emotionally disturbed in the 1985-86 and 1986-87 school years in the NLTS sample dropped out - a larger percentage than in any other disability classification. Further, $44 \%$ of students identified as having an emotional or behavioral disorder had been arrested within

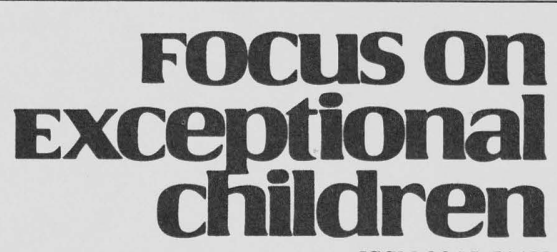

ISSN 0015-511X

FOCUS ON EXCEPTIONAL CHILDREN (USPS 203-360) is published monthly except June, July, and August as a service to teachers, special educators, curriculum specialists, administrators, and those concerned with the special education of exceptional children. This publication is annotated and indexed by the ERIC Clearinghouse on Handicapped and Gifted Children for publication in the monthly Current Index to Journals in Education (CIJE) and the quarterly index, Exceptional Children Education Resources (ECER). It is also available in microfilm from Xerox University Microfilms, Ann Arbor, MI. Subscription rates: Individual, \$27 per year; institutions, $\$ 36$ per year. Copyright (c) 1992, Love Publishing Company. All rights reserved. Reproduction in whole or part without written permission is prohibited. Printed in the United States of America. Second class postage is paid at Denver, Colorado. POSTMASTER: Send address changes to:

\section{Love Publishing Company \\ Executive and Editorial Office \\ 1777 South Bellaire Street \\ Denver, Colorado 80222 \\ Telephone (303) 757-2579}
Edward L. Meyen
University of Kansas
Glenn A. Vergason
Georgia State University
Richard J. Whelan
University of Kansas Medical Center
Stanley F. Love
Publisher
Holly T. Rumpler
Senior Editor

2 years after leaving school (Valdes, Williamson, \& Wagner, 1990).

Findings from the Washington statewide follow-up study (Neel, Meadows, Levine, \& Edgar, 1988) and the Iowa state follow-up study (Frank, Sitlington, \& Carson, 1991) broaden and confirm the findings of the NLTS on the postsecondary adjustment of students with emotional or behavioral disorders. Neel and his colleagues (1988) found that only $60 \%$ of the youths who had graduated or aged out of 21 school districts in Washington between 1978 and 1986 were employed; in contrast, $73 \%$ of a comparable nondisabled cohort were employed at the time of their study. They also found that only $8 \%$ of the nondisabled former students were unengaged (not working or pursuing postsecondary education or training), whereas $31 \%$ of the former students identified as having a behavior disorder were unengaged.

Frank and his colleagues (1991) compared former students with behavior disorders who had dropped out of school with those who had graduated. Of former students from the classes of 1985 and 1986 that they studied, 58\% of the graduates versus $30 \%$ of the dropouts were employed full- or part-time.

Looking beyond disability categories, the National Longitudinal Transition Study also reported student demographic characteristics and behaviors associated with failing grades and dropping out. Analyses revealed that younger students, males, and minorities among the sample of disabled youths studied were more likely to receive failing grades and to drop out of school. Behaviors and experiences associated with these negative events included absenteeism, lack of involvement in a school or community group, disciplinary problems in school, and low socioeconomic status (Wagner, 1991).*

\section{WHERE WE'VE BEEN}

The idea that troublesome youngsters require a different school program than other students was implemented more than 100 years ago with the first separate classes in New York (Hewett \& Forness, 1977). When compulsory attendance laws were enacted at the turn of the century and a more diverse group of young people enrolled in schools, special classrooms for "unmanageable, incorrigible, defective pupils" were established (Tropea, 1987). These early exam-

\footnotetext{
*Variability associated with failing grades, dropping out, and socioeconomic status (SES) were accounted for by behavioral variables such as absenteeism and disciplinary problems. In the absence of these variables, SES as measured by head of household education was significantly related to lower likelihood of receiving failing grades.
} 
ples of school restructuring were ostensibly motivated by desire to protect children from academic failure and social rejection (Leinhardt \& Pallay, 1982).

The special classes, however, also represented organizational accommodation that allowed schools to exclude students from the regular classroom and at the same time comply with the compulsory attendance legislation (Carrier, 1990; Tomlinson, 1982; Tropea, 1987). In the latter view, the growth of special programs was facilitated by tacit understandings that schools could maintain order by isolating certain pupils. During the first half of the 20th century, many school districts developed special class programs for one or more groups of children with disabilities, but programs developed for children with emotional or behavioral disorders were most often special schools or were associated with hospital settings (Coleman, 1986; Kauffman, 1989a).

The popular and professional images of children with emotional or behavioral disorders and the treatments they received were shaped by biographical accounts of children such as Dibs (Axline, 1964) and Jordi, Lisa, and David (Rubin, 1962). These children, variously described as deeply disturbed and childhood schizophrenic, received psychotherapy in special residential and day treatment centers. As archetypes for students with emotional or behavioral disorders, the images have endured. In the late 20th century, however, children served in special education programs are as likely to resemble the African-American youths in Boyz ' $N$ the Hood as they do Dibs, and Jordi, Lisa, and David.

\section{TWO SIGNIFICANT STUDIES}

A seminal study completed in 1964 by Morse, Cutler, and Fink examined $75 \%$ of all public school classes for the "emotionally handicapped" then in existence. Incorporating data from teachers, administrators, and students, the research captured diverse elements of those programs and resulted in a rich profile that is useful as a point of reference for scrutinizing current services. In 1987, Grosenick, George, and George compared this work with an exhaustive investigation conducted as part of the National Needs Analysis in Behavior Disorders.

A striking similarity between the Morse et al. and Grosenick et al. investigations is that both studies identified return of students to the regular class as the primary goal of the programs. Unfortunately, both studies found that only a small number of students realize this goal. A distinct characteristic of programs seems to be this gap between intent and outcome-a disparity that continues to generate debate as current reform movements propose corrective measures.

In keeping with these findings, screening and diagnostic mechanisms are articulated in greater detail than are procedures for determining when students no longer need special education services. Grosenick et al. (1987) found that $98 \%$ of districts reported formalized referral criteria but only $51 \%$ had written exit procedures. Without minimizing the problems involved in assessment and identification, Morse, Cutler and Fink's observation in 1964 that "it was much easier to get a child into a program than it was to get him out again" (p. 26) remains an accurate description.

Both studies concluded that students with behavior disorders are underserved; currently, less than $1 \%$ of the schoolaged population with emotional and behavioral disorders are identified and receive services (U.S. Department of Education, 1991b). Estimated prevalence figures, however, range from about $8 \%$ to $10 \%$ of the school-age population (Knitzer, Steinberg, \& Fleisch, 1990). In addition, two-thirds of youths do not receive the mental health services they need (Knitzer, 1982).

Certain aspects of programming have changed during the last two and a half decades. The number of programs has increased dramatically; virtually all have been created since 1975 and passage of the Education for All Handicapped Children Act (PL 94-142) (Grosenick, 1989). Most notably, the methods of funding have changed and parents now have procedural protections in assessment, identification, and placement. The advent of more programs for adolescents has been a particularly welcome development. Programs clearly enjoy a different status with the requirements of PL 94-142. For instance, Morse et al. (1964) found that, because some districts considered classes to be experimental, they were disbanded if judged unsuccessful.

\section{CURRENT ISSUES}

\section{Least Restrictive Environments}

A primary issue for those concerned with the education of students with emotional or behavioral disorders involves determining the most appropriate setting within which to provide services. The concepts of segregated versus integrated services continue to be debated. Discussion often involves interpretations of the least restrictive environment (LRE) clause of the Individuals with Disabilities Education Act (IDEA, formerly the Education for All Handicapped Children Act, PL 94-142), which codified the belief that educating children with disabilities with their nondisabled peers is 
the preferred model. Although the LRE requirement has been reviewed extensively in the literature (Brady, McDougall, \& Dennis, 1989) and is not discussed here, it is significant that states and local education agencies must devise a range of placement options to ensure that youngsters can be educated in the regular class or in a setting least removed from it.

The frame of reference for the continuum of services is distance from the regular classroom. Typically, the continuum model includes placement options within the regular school: the regular classroom with support services, the resource room, and the separate or self-contained class. More restrictive placements apart from the regular school include special day schools, residential programs, hospitalization, and homebound instruction.

In some respects, the scope of available programs has expanded in recent years. Even so, "a viable continuum of services including both school and community-based options does not exist" (Grosenick, 1989, p. 13). Since Morse et al.'s early analysis in 1964, the separate classroom continues to be the setting most frequently employed for providing educational services to youths with emotional or behavioral disorders.

Table 1, taken from the 13th Annual Report to Congress on the Implementation of PL 94-142, indicates where students with emotional and behavioral disorders are currently educated.

\section{TABLE 1}

Primary Educational Setting for Students with Emotional or Behavioral Disorders

$\begin{array}{lr}\text { Regular classroom } & 14.1 \% \\ \text { Resource room } & 30.0 \% \\ \text { Separate class } & 35.8 \% \\ \text { Separate school } & 13.4 \% \\ \text { Residential facility } & 3.8 \% \\ \text { Homebound/Hospital } & 2.9 \%\end{array}$

These figures apply to 382,570 students aged 6-17 identified as having an emotional or behavioral disorder and receiving special education services.

Source: Data from Thirteenth Annual Report to Congress on the Implementation of the Individuals with Disabilities Education Act (U.S. Department of Education, 1991).

Although a complete range of program options was conceived as a flexible organizing scheme to maximize schools' ability to adapt to individual differences, placements for adolescents with emotional or behavioral disorders suggest that they are educated most often in separate class settings. Students may or may not spend time with peers in regular classes; practices vary widely by state (Danielson \& Bellamy, 1987; McLaughlin \& Owings, in press; U. S. Department of Education, 1991b) and by local school districts. In addition, options are more restrictive than those available to students with other disabilities (U. S. Department of Education, 1991b).

This pattern of variability cannot be explained by the nature or instructional needs associated with this disabling condition. Various explanations have been proposed, including difficulties with designing services in rural areas, ambiguous definitions of emotional or behavioral disorders, limited availability of program options (Danielson \& Bellamy, 1989; Kauffman, Cullinan, \& Epstein, 1987), and social, political, and economic factors that influence decision making (Algozzine \& Korinek, 1985; Leone, 1989; McLaughlin \& Owings, in press). More recently, assumptions about disabilities that influence provision of services in settings apart from the regular class also have been implicated. In any event, both the letter and the spirit of the LRE mandate are compromised by the limited scope of placement options. The current status of services to youths with emotional or behavioral disorders will affect the development of any inclusive school restructuring efforts.

\section{Who Is Behavior Disordered?}

A second major issue revolves around who to include in programs for children with behavior disorders, or what constitutes a behavioral disorder? Unlike youngsters with multiple disabilities and sensory impairments, children identified as "seriously emotionally disturbed" have a disability that is primarily social in nature. Current conceptualizations about troublesome behavior foster the separation of those youngsters from their nonidentified peers and contribute to our inability to appropriately educate youths who have emotional or behavioral disorders. Further, our beliefs about the nature of disordered behavior have implications for restructuring schools.

In a position paper on definition and identification, the Council for Children with Behavioral Disorders (1987) posits that problems associated with unserved youths are attributable to poorly defined and restrictive federal eligibility criteria. Another potential reason for the numbers of unserved youths and the discrepancy in percentage of children served from state to state is the problem associated with the 
referral, assessment and placement process. Cultural bias in the instruments used to screen and assess youths suspected of having behavior disorders, and flaws in the psychometric properties of those instruments, can contribute to underidentification and variability in service levels (National Coalition of Advocates for Students, 1985). Currently in several states attempts are being made to exclude students identified as "conduct disordered" from special education programming. This move involves labeling those students "socially maladjusted" and identifying the locus of their troubles as external rather than internal (Forness, 1992; Maag \& Howell, 1992; Nelson \& Rutherford, 1990).

A review of other perspectives on disordered behavior also casts doubt on the veracity of the assumption that emotional disturbance and behavioral disorders are things that students "have," and that we can identify and appropriately serve those youths. Even though all children differ on a range of social, intellectual, and emotional constructs, the concept of emotional or behavioral disorders in school settings can be viewed as the creation of those empowered to establish and direct the schooling of the nation's children. As such, definitions and the process of identifying those who are "eligible" for services is essentially a social act that reflects power balances in the larger community (Ford, Mongon, \& Whelan, 1982). Just as rates of identification vary from state to state, so do the percentages of students from various racial and economic groups identified as seriously emotionally disturbed (National Coalition of Advocates for Students, 1985; Office for Civil Rights, 1978-79). Social, political, and economic factors, among other things, drive assessment and decision making in special education (Algozzine \& Korinek, 1985), as the current controversy on eligibility of "socially maladjusted" children confirms.

To general educators, the person-centered perspectives of special educators and others concerned with troubled youths fit nicely into the current structure of systems designed to deliver a uniform product to all children, despite the range of individual, racial, cultural, and experiential differences they bring to school. An alternative explanation to the prevailing assumption (that behavioral disorders and emotional disturbances are things that some students have) is to understand that these disorders, rather than reflecting only child characteristics, also reflect the characteristics of the schools and agencies that serve them. Because the process of identifying and assessing involves a great deal of discretion on the part of the professionals involved, those who are identified do not conform to the normative values of the current social order and represent a poor fit within the school system.

\section{Federal Mandates and Troublesome Behavior}

A problem related to defining who is eligible for services is that educators have allowed federal legislation (Individuals with Disabilities Education Act or IDEA) mandating service to all children identified as "seriously emotionally disturbed" (SED) to dictate to the profession and to the public schools criteria for eligibility for programs and services. Although federal definitions of SED set some powerful parameters for who may receive services under IDEA, states can broaden their eligibility criteria, focus on preventing serious disorders and, for example, serve students with incipient behavior problems if they choose.

The federal statute reinforces a person-centered or personas-problem perspective by providing additional financial support to school districts for each student identified as "seriously emotionally disturbed." Accordingly, special educators devote minimal attention to alleviating problems that create disturbance within school settings or to rectifying maladaptive relationships between students and teachers that propel students toward identification as students with special needs. [For exceptions to this rule, see discussion and reports on consultation models (Graden, Casey, \& Bonstrom, 1985; Knight, Meyers, Paolucci-Whitcomb, Hasazi, \& Nevin, 1981; Polsgrove \& McNeil, 1989; Rosenfield, 1992). For alternative conceptualizations of disordered behavior, see Leone (1990), Rhodes and Tracy (1972), and Apter (1982).]

\section{A Macro-Perspective}

In contrast to person-centered conceptualizations of troubling behavior reinforced by federal mandates are perspectives that acknowledge the construction of deviance and disability by both individuals and organizations. A macro-perspective on disordered behavior posits that the manner in which institutions are organized and the cultural and social forces that shape behavior contribute to the development and maintenance of what is defined as disturbed behavior (Bogdan \& Kugelmass, 1984; Everhart, 1990; Tomlinson, 1982).

From this perspective, the ways in which schools are organized contribute to the problems that youths experience. In addition to the cultural transmission model (Kohlberg \& Mayer, 1972) that currently dominates public schooling, the relationship between teachers and students, the role of authority in the school, the hierarchical relationships among teachers, principals and administrative staff, and the size of schools and classes in many urban and suburban districts are all factors that may contribute to troubling behavior in school settings. 
To take one example, the current size of many public secondary schools is based on one of the principles of industrial organizations: economies of scale. In the absence of a pedagogically sound principle for organizing schools with 2,000 to 3,000 or more pupils, personal experience suggests that distance between teachers and pupils is greater and student alienation is greater in large schools than in small ones.* Delinquent behavior in junior high schools has been associated with large class sizes and poor attendance; in senior high schools delinquent behavior has been associated with low academic quality of the school and transience among the student population (Hellman \& Beaton, 1986). Further, the research literature suggests that weak attachment to school is associated with poor school performance (Hirschi, 1969) and school dropout and delinquency (Elliot \& Voss, 1974)

Clearly, past experience and research related to education of adolescents with severe behavior disorders suggest a number of areas in which reconsideration or reform is needed. Furthermore, the research and experience has yielded valuable information about how to make meaningful changes in these students' lives. Yet success of the interventions will depend largely on the context in which they will be applied, and that context is public education.

Although public education historically has not welcomed these students, the possibility for change exists in current restructuring efforts underway in public education in the U. S. as well as Canada and other nations. These initiatives provide an opportunity for schools to reexamine their missions and to acknowledge the diversity of students asking for education. If schools seize the opportunity, they may have the flexibility to truly promote success for all students. If, however, schools choose to interpret restructuring narrowly, there is great risk that students with emotional and behavioral disorders will remain segregated and ignored.

\section{THE CHALLENGE AND OPPORTUNITY OF RESTRUCTURING AMERICAN EDUCATION}

Today, at the beginning of this new decade, a climate of change is sweeping across this nation's school districts. As citizen disenchantment with education increased, politicians, lawmakers, and the education profession responded with a number of administrative and program initiatives, as well as a variety of special commissions and task forces, reports, and other pronouncements. Beyond the rhetoric is evidence of

\footnotetext{
*At the Old Mill School complex in Anne Arundel County, Maryland nearly 4,000 students attend school in one building. The building is organized into one high school and two middle schools.
}

major readjustment in educational systems and tremendous amounts of energy expended in the name of "restructuring" education. Some (Toch, 1991; Special Study Panel on Education Indicators, 1991) have called the changes unprecedented in the history of American education, for the breadth of concern and for the nature of the changes being suggested.

The national mood offers tremendous opportunity for schools and school districts to rethink their philosophy and mission for education and the way in which they educate their students. Depending on the directions of those changes, restructuring can provide a way to bring students with challenging behaviors and special needs into the schoolhouse, or it can further segregate and disenfranchise them.

\section{Earlier Reform Initiatives}

The current restructuring movement is an extension of the earlier reform initiatives, begun during the early 1980 s, that focused on increasing accountability and standards for students and schools. These earliest initiatives were characterized by state-level mandates such as minimum competency testing, increased requirements for teacher certification, and mandated core curricula focusing on basic skills. These reform attempts were heavily bureaucratic and created new mandates and standards for schools. Although they centered attention on the need to improve student performance, they did little to address the fundamental problems of how students actually were being taught in the schools.

In 1986 the Carnegie Forum on Education and the Economy's report, A Nation Prepared: Teachers for the Twentyfirst Century (Carnegie Forum on Education and the Economy, 1986), called for a new phase in the national campaign to reform and improve American public education. The report stated that the 1980s had been a time of ferment for American schools and a number of measures had been adopted to increase institutional quality and effectiveness. The report also argued that more profound and deeper changes were now needed. Specifically, the report offered one thesis that gained widespread interest and support:

\footnotetext{
Restructure schools to provide a professional environment for teachers, freeing them to decide how best to meet state and local goals for children while holding them accountable for student progress . (p. 55)
}

This postulate was significant for the educational reform movement because it represented a shift away from earlier efforts that emphasized a top-down approach that merely fine-tuned the elements within the current public education system. The report cited the changing demographic and eco- 
nomic trends in the U. S. and noted the need to prepare students for a more competitive and global economy. Students, it stated, need to learn how to think critically, to be lifetime learners; imparting such new knowledge will require a fundamental restructuring of the American education system. A restructured school should be characterized by a professional environment in which staff, parents, and the community, guided by state and local goals, jointly define the school's mission for education as well as the outcomes and process for educating the school's students.

The report supported the work of a number of scholars in education who were actively engaged in research involved in defining elements of high-quality schools, as well as developing models for new ways to educate students. The effective school literature (see Northwest Regional Educational Laboratory, 1990, for a synthesis of that extensive literature) identified a number of factors related to high-performing schools. Others, such as Sizer (1984), Levin (1990), and Goodlad (1984), offered specific models for changing the way schools conceptualize education and the way in which instruction is delivered. Concepts such as teaching critical thinking and "higher-order thinking processes" entered the curriculum domains, as did constructionist theories regarding instruction (e.g., whole language and whole math). In addition, the role of teachers was redefined as being less didactic and authoritarian and more as mentor or facilitator.

National interest in restructuring continued to grow throughout the 1980s with the publication of many reports including several that addressed the plight of disadvantaged and culturally diverse students. In particular, reports such as America's Shame, America's Hope: Twelve Million Youth at Risk (Smith, 1988) and The Forgotten Half: Non-College Youth in America (William T. Grant Foundation, 1988) focused attention on the fact that most of the educational outcomes valued by the schools were designed for students going on to college-less than half of the nation's students. Changing demographics and changing workplace demands were creating the need to educate the lower class and not merely train them (Toch, 1991). The concept of equity was broadened to mean that all students have a right to the same outcomes and not merely to access public education, and the concept of "all students can learn" became a philosophical underpinning of national restructuring efforts.

\section{National Strategy for Education}

In 1990 the nation's governors and the President came together at an Educational Summit to define a vision for Amer- ican education. Six goals generated at that summit were incorporated into America 2000 (U. S. Department of Education 1991a), which established a national strategy for education for the Bush administration. America 2000 presents a four-part strategy for meeting the six goals:

1. The first strategy stresses accountability and calls for creation of consistent national performance standards in five core subject areas and the creation of a set of national tests to measure the standards. Report cards of school (and student) performance on the test are to be given to parents and the general public to provide comparable information on how well the schools are doing.

2. A second strategy calls for establishment of a new generation of schools supported by the business community. The plans also call for creation of some 535 New American Schools that will represent "one-of-a-kind high-performance schools" (U. S. Department of Education, 1991a, p. 25).

3. The third strategy focuses on adult literacy and an upgrading of job skills in the existing workforce.

4. The final strategy is a call for local community endorsement and support of the policy.

None of these strategies, or proposals to establish the agenda, mentions students with disabilities ("'America 2000' Choice Plan," 1991).

America 2000 is a political document laden with a particular ideology and view of what education should be. There is a clear message that educational innovation should be locally determined and that federal and state regulation should promote flexibility and choice and not stifle schools with required programs. The policy also narrowly defines education in terms of academic achievement. Schools are for academics; students' other needs belong to other agencies.

In contrast to the emphasis on flexibility in how schools operate, the same ideology proposes a set of national student standards or outcomes that are highly academic and will be defined in a national test. These outcomes will be used as standards against which all schools will be held accountable. Thus, schools may educate in the ways they choose as long as they can attain the same student academic outcomes. These two parts of restructuring-defining a school's mission and defining student outcomes - are perhaps what are generating the greatest controversy and concern among many in the education community.

Despite the move toward increasing local control in education, state school superintendents, state boards of educa- 
By the year 2000:

\section{AMERICA 2000 GOALS}

1. All children in America will start school ready to learn.

2. The high school graduation rate will increase to at least 90 percent.

3. American students will leave grades four, eight, and twelve having demonstrated competency in challenging subject matter including English, mathematics, science, history, and geography; and every school in America will ensure that all students learn to use their minds well so they may be prepared for responsible citizenship, further learning, and productive employment in our modern economy.

4. U. S. students will be first in the world in science and mathematics achievement.

5. Every adult American will be literate and will possess the knowledge and skills necessary to compete in a global economy and exercise the rights and responsibilities of citizenship.

6. Every school in America will be free of drugs and violence and will offer a disciplined environment conducive to learning.

Source: U. S. Department of Education, America 2000: An Education Strategy (Washington, DC: Government Printing Office, 1991).

tion, and state legislatures have continued to push forward with their own statewide initiatives and mandates, most notably in the area of performance assessment. These statewide programs reflect a tightening of state control at the same time that local districts are being encouraged to create their own successful schools and move program and budget decisions to the school. Both tension and policy ambiguity are created by the increase in state-level reform efforts and local district initiatives to restructure (Fuhrman \& Elmore, 1990). Despite the ambiguities and the undefined policies, there is little doubt of a national climate for change in education. As long as presidential attention is directed toward education, the changes will continue.

\section{SCHOOL RESTRUCTURING AND SPECIAL EDUCATION}

Even though special education has not been included explicitly in the national restructuring agenda, these programs undoubtedly will be affected by any changes in the larger educational environment. Yet, to think that special education as a specialized program is passively awaiting the outcomes of restructuring would be a mistake. Instead, special education as a professional field has been grappling with calls for systemic restructuring of how services are provided, and to whom.

For much of the past decade, policymakers, researchers and scholars, and practitioners have been concerned with special education effectiveness and efficiency. The poor postschool outcomes attained by former special education students (Edgar, Levine, \& Maddox, 1986; Hasazi, Gordon, \& Roe, 1985; Wagner, 1991), as well as research documenting the lack of gains of students in special education classrooms (Carlberg \& Kavale, 1980), began to call into question the efficacy of separate and specialized services. Further, Gartner and Lipsky (1989), Stainback and Stainback (1984, 1989), Skrtic (1991), and others point to the confusing and "erroneous" classification systems designed to determine eligibility for special education as being of little use in instruction and as unnecessarily stigmatizing some students and unfairly denying services to others.

These researchers, along with a number of others involved with students who have severe disabilities (Biklen, 1989; Sailor, 1991; Thousand \& Villa, 1991), call for a rethinking of how schools provide special services, to include proposals such as merging special and mainstream educational administration and providing special education services as part of the regular classroom. Recently, Hehir, Stariha, and Walberg (1991), writing in support of the restructuring of special education, noted that special education programs evolved into process-driven systems, in large part out of the necessity to quickly implement a national policy of providing a free and appropriate public education for students with disabilities following enactment of PL 94-142. They argue that now there is a need to confront some of the persistent problems in special education, such as making eligibility decisions and reducing segregation of students within the restructuring school system by breaking down the traditional structure of special education and holding schools accountable for the outcomes for students with disabilities.

Proposals such as those discussed above have been soundly criticized (David, 1989; Fuchs \& Fuchs, 1988; Kauffman, 1989b; Kauffman, Gerber, \& Semmel, 1988). Indeed, there are many unknowns about how the changes might impact services to all students with disabilities. Yet, broad changes in policy perspectives parallel the restructuring movement in mainstream education. As Skrtic (1991) 
noted, the arguments for restructuring special education involve both ethical and philosophical issues. These issues are in line with a reconceptualization of education in general. Special education can contribute to creating a broader, more inclusive mission for education as well as providing a large and powerful set of proven interventions for helping all students learn more effectively.

To accomplish that, special education must be guided by a broader vision of whom it might serve and how students can be served. The broader educational restructuring movement and the more specific concerns of special education have come together in time to create an environment that can support and encourage change in the way public schools serve students with behavior disorders. Unless leadership for those changes is evident, however, the risk is high that these same students will be ill-served by the current movement. Even though risks are present, some evidence indicates that restructuring is changing the perceptions and culture of the school to support diversity and accommodate all students regardless of disability.

\section{RESTRUCTURING THE LOCAL SCHOOL}

The Center for Policy Options in Special Education at the University of Maryland, College Park, was funded by the Office of Special Education Programs to examine the issue of school-site restructuring and to identify, through interviews, site visits, and meetings with a variety of key general and special education leaders, the issues related to students receiving special education. The Center visited more than 15 school districts across the nation and conducted telephone interviews with an additional 45 . Further, the Center hosted meetings of various general and special educators to obtain their perspectives and experiences with restructuring.

From these discussions and interviews, some of the major features of school-site restructuring emerged (Center for Policy Options in Special Education, 1992). Among them, three areas are perhaps the most critical for students with disabilities: defining the mission and goals for restructuring; establishing student outcomes; and identifying the curriculum.

\section{Defining the Mission for Education}

Restructuring almost always begins with a clear statement of the mission and vision for education. This mission statement is operationalized through a set of goals that focuses attention at the school site on specific outcomes and areas for restructuring. Typically, these mission statements refer to creating effective education for all students as measured by performance on some set of outcomes.

Some mission statements and the accompanying goals go beyond traditional views of education to define a broader vision for schools. These new mission statements view schools not as narrow dispensers of academic curriculum but instead as the hub of the services students need to be educated, including health and mental health. These broader visions acknowledge student diversity and reflect the belief that all students may require, at some point in time, additional support. Such full-service schools attempt to expand their missions and broaden concepts of program eligibility and to create permeable membranes between programs by fostering collaboration among educators and other specialists.

Unfortunately, some school districts engaged in restructuring have defined mission statements that promote quality for all students, but the accompanying goals, school performance standards, and program directives exclude consideration of special education students and programs (Center for Policy Options in Special Education, 1992). In many instances, special educators as well as parents of students with disabilities have not been included in the process of creating mission statements or defining goals. Those activities have been highly political and directed by a superintendent or school board without wide community input. In the Policy Center inquiries, special education administrators and teachers reported feeling that their noses were pressed against the window, trying to become part of the planning teams that are developing school or district reorganization plans or defining the outcomes.

In contrast, in districts where special education leadership has been involved in restructuring, the message is clear and unambiguous, a message of one system with one mission that includes students with disabilities. In those districts, all plans and directives include special education, and policies, such as those governing outcomes or curriculum, are broad enough to encompass all learners. Furthermore, instruction is more collaborative and supportive.

\section{Expanded Missions for Adolescents with Behavior Disorders}

Examples of programs reflecting a broader concept of education that includes adolescents with emotional or behavioral disorders were reported by Knitzer, Steinberg, and Fleisch (1990) in At the Schoolhouse Door. Restructuring efforts ranged from relatively minor design changes to major overhauls of service delivery, which included frank examination of program goals. Some of the models center on increas- 
ing collaboration among teachers within a building. An example is Project Merge in Olympia, Washington, for retraining regular classroom teachers and resource teachers to provide remedial academic instruction and crisis intervention services in regular classrooms - in effect altering the classroom environment rather than labeling individual students. The apparent success of the project, as measured by decreased referrals to special education, is also a cautionary tale in that the district's ability to provide services in this manner was being challenged even as the authors visited.

A 5-year follow-up study in one school district indicates that full-time integration of students with emotional or behavioral disorders into regular education classes is more successful than resource room programming (Affleck, Madge, Adams, \& Lowenbraun, 1988). The conclusion was reached by considering indicators of academic and social competencies and includes the intriguing information that high school students who had been in integrated classrooms were staying in school; more of those educated in resource rooms had dropped out.

If schools are only beginning to explore efforts to modify the design and use of resource programs, the self-contained classroom, which educates a larger percentage of students, receives less attention. Much the same can be said about day treatment and residential schools. Often, deliberation surrounding those programs focuses on perceived inadequacies of the curriculum, instructional strategies, and behavior management systems.

\section{Links Between Mental Health and Education}

In addition to programs that are seeking more in-house collaboration, other restructuring efforts involve more linkage between public schools and mental health systems in attempts to provide comprehensive services. The goals of this concept are best captured by the term "therapeutic case advocacy" (Knitzer, 1982), which suggests coordination of services to youngsters and their families by education, juvenile justice, child welfare, vocational rehabilitation, and mental health agencies. This intention "reflects a reconceptualization of emotional disturbance" (Young, 1990, p. 120) because modification of the match between person and environment, rather than only individual characteristics, is identified as the central concern in the change process. These models also reflect schools' commitment to educate the whole student and not just create better outcomes in narrow academic areas.

The concept of providing collaborative services is commonly applauded because of suppositions that youngsters with emotional or behavior disorders present complex diffi- culties that are best ameliorated by multifaceted support systems (Forness, 1988; Grosenick, 1989; Knitzer et al., 1990; Melton, n.d.; Nelson \& Pearson, 1991; Young, 1990). Other advantages of providing collaborative services through individual case management include elimination of the confusion and delays that too often result when individuals attempt to maneuver through the organizations of multiple agencies (Forness, 1988); resolution of funding issues (Forness, 1988); and the ability to reach more people (Forness, Sinclair, \& Russell, 1984; Melton, n.d.). Interagency agreements are not forged without difficulty, and "turf" issues concerning responsibility for provision of services and funding continue to plague some programs (Forness, 1988; Grosenick, George, \& George, 1987; Knitzer et al., 1990; Nelson \& Pearson, 1991).

The National Association of State Boards of Education reports that most states have interagency partnerships (Cohen, 1989). These include programs such as New Jersey's School-Based Youth Services, which offers a wide array of social service supports to adolescents, and the Maryland interagency agreement created by the state legislature to coordinate education, health, and mental hygiene services for "special needs" youth.

Also, local government agencies have developed interagency models that include the schools. Specifically designed for youngsters with emotional or behavioral disorders, Ventura County, California, developed an interagency model designed to provide comprehensive, coordinated mental health services that enable children to remain in the community, attend and progress in the public schools, and avoid delinquent behaviors (Nelson \& Pearson, 1991). The Ventura model includes collaboration with schools, mental health, business and religious leaders, the juvenile court, and others.

A statewide pilot project, Bluegrass IMPACT, is Kentucky's plan to develop a flexible comprehensive system of care to children and youths with emotional or behavioral disorders (Nelson \& Pearson, 1991). Like the Ventura model, the Kentucky model involves interagency collaboration designed to keep youths in contact with families, schools, and communities rather than to place them in restrictive, out-ofhome placements. Flexible response teams that are part of Bluegrass IMPACT develop flexible support services for families, teachers, and communities.

Knitzer and her colleagues (1990) highlight the approach Montgomery County, Pennsylvania, has taken in self-contained SED classes. Teachers and clinicians jointly facilitate problem-solving groups that have proven effective in helping students to cope with issues such as transitions to regular education and have been credited with reducing teacher attrition. 
The Child and Adolescent Service System Program (CASSP) developed by the National Institute of Mental Health incorporates the elements considered essential to state-of-the-art comprehensive treatment. These communitybased programs coordinate multiagency interventions, view family involvement as crucial not only to treatment but also to program planning, provide services in least restrictive clinical and educational settings, and seek to tailor services to the needs of individual youngsters.

An evaluation of family satisfaction and involvement in a Dane County, Wisconsin, program based on these principles found that use of community services increased and rates of institutionalization dropped (Greenley \& Robitschek, 1991). Families reported satisfaction with their involvement in designing and implementing treatment services. Even though these early results are promising, methodological problems suggest that the findings be interpreted cautiously.

The programs mentioned here are examples of the trend toward interagency collaboration. Efforts typically involve redeployment of staff, community-based treatment, and a systems approach to meeting the needs of youths. An approach based on the principle of inclusion can move schools toward creating programs that maximize learning for all students and away from thinking only about complex procedures or regulations that allow some students to be put into another system called special education. Inclusion at the beginning of restructuring avoids the "your kid/our kid" notion, which permits abdication of responsibility for educating or improving outcomes for all students.

These are just some of the more innovative and promising models and systems that define a broader vision for serving adolescents with emotional and behavior disorders. Many of the school districts seeking to enhance collaboration are motivated by a fiscal need to maximize all human resources and to avoid duplication of services. Among other reasons for fostering more collaboration is the need to create more cohesive programs for students without fragmenting instruction. Whatever the motivation, the impetus in restructuring is for greater collaboration and program flexibility (Center for Policy Options in Special Education, 1992). Collaboration, however, does seem to be easiest to achieve at the elementary level and more difficult in comprehensive high schools.

\section{Establishing Outcomes for Students}

Closely tied to how a school defines its mission are the outcomes defined for its learners. Setting a mission statement with inclusive goals is easier than deciding how schools should be accountable for all types of learners. Within the outcome-driven context of today's restructuring, student standards or outcome indicators have to reflect the full diversity of the students served in schools. That means that acceptable and measurable outcomes for students with behavior disorders must reflect the meaningful outcomes expected for those students.

\section{Narrow Versus Broad Outcomes}

The current emphasis on narrow outcomes of academic achievement reflect a narrow view of education and one that is likely to exclude many students. Yet, some states and districts are focusing on broader constructs with outcomes including social relationships, citizenship, and even postschool outcomes such as employment or participation in postsecondary education.

For example, Maine's "Common Core of Learning" (Commission on Maine's Common Core of Learning, 1991) has a range of student outcomes in the areas of academics, personal and social development, and problem solving. Student competency in these areas will serve as the basis for instruction as well as evaluation. In the Kentucky statewide reform, outcomes will be assessed in a variety of areas ranging from academics to mental and physical well-being (Kentucky Department of Education, 1991). Students with disabilities are included in the assessments of these outcomes, and schools are held accountable for their performance. Outcomes such as those just delineated direct instruction toward broad areas of child and adolescent development and force the school's attention into creating broad curriculum.

Another approach to defining outcomes for students with disabilities is exemplified by a system developed by the Michigan Department of Education (Frey, 1991). Separate outcomes for different disabilities have been defined, and a set of assessment procedures has been developed. Outcomes for students identified as behaviorally disordered emphasize adjustment and socialization and differ according to age. Specific examples of indicators for a fourth grader identified as having an emotional impairment are: knowing concepts of good/bad, appropriate/inappropriate, and moderate/excessive. Although outcomes such as these allow for greater specialization, they do not substitute for those established by the larger educational system and can result in greater curriculum and program segregation.

Finally, some view the outcomes of schooling broadly and see schools as accountable for some general student conditions. For example, Hornbeck and Lehman (1991) present the outcomes of school for all students as either appropriate post-secondary education or competitive employment (with or without support). Schaffner and Buswell (1991) espouse 
positive social relationships as the most important educational outcomes for students with disabilities, particularly those with the most challenging learning and behavioral difficulties.

However they are identified, outcomes direct a school's change efforts, ultimately defining what schools will teach and how they will focus their resources. In short, they drive the system. To the extent that they reflect a broader conceptualization of what education should mean for students, the more flexible and humane the instruction will be.

Adjustment as a Goal Along with Achievement

Students with emotional and behavioral difficulties need inclusive outcomes. Because these students are more likely to fail in the academic areas, one of the greatest concerns about the current reform agenda and its impact on students with disabilities is the emphasis on academic excellence (Algozzine, Ysseldyke, Kauffman, \& Landrum 1991; Carnine \& Kameenui, 1990; Sapon-Shevin, 1987; Shepard, 1987). We add another dimension to the debate: social needs. Unlike other types of differences among young people, youngsters with emotional or behavioral disorders have a disability that is primarily social in nature. Adolescents with emotional or behavioral disorders are among those who are most invisible in schools as they are now structured.

Students educated in restrictive settings, like Jordi, Lisa, and David, as well as youths like Dough Boy and the characters from Boyz ' $N$ the Hood who may be excluded from school, have limited opportunities to interact with peers or teachers in regular classes. They either are pushed out or leave voluntarily because of persistent failure to succeed in the schools as they are defined. These youths are often educated in separate settings, they drop out, they are "pushed out," and they are frequently suspended. When they attend school, they occasionally receive in-school suspension. Many of these young people are perceived as expendable and even unreachable.

The effect of current policies on many students with emotional and behavioral disorders is clear. The effects of restructuring proposals will depend to a large extent on how the school chooses to define education for these students.

Restructuring agendas that address only academic excellence are incomplete. If academic development is the only educational objective and other aspects of learning are dismissed as inappropriate and inconsequential, many youngsters in special education will be shortchanged and all students will miss a vital part of schooling.

Consider also that the "preventative function of special education for seriously emotionally disturbed children would be obviated, given that disordered social-interpersonal learning can play a causative role in academic failure" (Kauffman, Cullinan, \& Epstein, 1987, p. 182). Programs for these students are characterized as remedial, and recommendations for improving services have consistently recommended strengthening their preventive roles (Grosenick, George, \& George, 1987; Knitzer et al., 1990; Morse, Cutler, \& Fink, 1964).

We are not, of course, disparaging academic excellence. We are saying that goals directed only toward acquiring subject area content take a narrow view of education. Further, academic proficiency is necessary but not sufficient for graduating students to participate fully in their communities. Proposals that limit the definition of education in this way present a particular irony for students whose difficulties in school have led to the label "seriously emotionally disturbed"which implies the need to learn and practice social skills.

\section{The Curriculum Conundrum}

From inception of the restructuring movement, a fundamental theme was to change what students were taught. Critical thinking skills and similar process-oriented concepts entered the educational vernacular and educational restructuring efforts. Outcomes define curriculum. As the old adage goes, "What gets measured gets taught." Thus, the America 2000 vision of academic excellence and the impetus to create national tests conceivably could drive schools into implementing a narrow curriculum, actually steering education in the opposite direction of the original intents of restructuring.

During the investigation of school restructuring, The Center for Policy Options in Special Education heard little about curriculum. Clearly, outcomes were consuming the attention of district policymakers and program administrators. Yet, some suggested that the issue of what to teach students with disabilities in the context of restructuring was becoming a major concern. For example, in one state that recently mandated successful completion of algebra for high school graduation, local directors of special education talked of increased referrals to special education in high school to avoid a course that many students could not complete and was not considered relevant to these students'outcomes. Several districts discussed the need to separate special education students at the secondary levels by offering an adapted curriculum to students who could not meet the rigors of the official district curriculum designated for all students. Students who do not have adapted curriculum may find that dropping out is the only alternative. 
In discussions of curriculum, key terms included "broad curriculum" and "flexible instruction." Still, there was a strong feeling that students with disabilities were entitled to the mainstream curriculum and should not be relegated to a separate, second-tier curriculum.

The implications for adolescents with behavioral and emotional difficulties are enormous. Particularly important is the need to respond to the characteristics of children and adolescents who attend our public schools. Schools should not short-change the Boyz 'N the Hood or create rigid programs that cannot meet their needs.

Over the years a number of alternative schools and programs have been developed with differentiated curriculum orientations that neither undereducate nor underestimate the students. Examples of schools with alternative curricula serving heterogeneous groups of students are the Harrison School in Minneapolis, Minnesota; Tall Oaks Vocational High School in Prince George's County, Maryland; City Lights in Washington, DC; and the Los Angeles County Court and Community Schools. The Harrison School and Tall Oaks are operated by public schools systems. City Lights is a private, nonprofit school serving public school youths. The Los Angeles County Court and Community Schools are operated by the Los Angeles County Office of Education in conjunction with the Los Angeles County Departments of Children's Services, Probation, and Mental Health.

Clearly, state and districtwide policies regarding curriculum, as well as textbooks and materials, must allow for curriculum flexibility and for differentiation within the comprehensive schools as well as within alternative schools. Without these features, even more students will become curriculum casualties.

\section{SUMMARY}

Skrtic (1991) succinctly stated the promise of school reform:

\begin{abstract}
In practical terms, both [special educators and general educators] seek an adaptable system in which increased teacher discretion leads to more personalized instruction through collaborative problem solving among professionals and client constituencies. (p. 176)
\end{abstract}

Eliminating an overly rational and bureaucratic system in favor of one that supports new ways of viewing student differences and celebrating student diversity is a common hope for those who are restructuring schools and those who are concerned with the education of students with behavior disorders. The climate is right for change, but only leadership and vigilance will ensure that the direction is correct. Many of the current strategies espoused in America 2000 and similar reform initiatives do not support diversity if it means something other than academic achievement. If the vision of those who promote school reform and restructured schools is limited, administrators and educational leaders will not see the Jordis, Lisas, and Davids or the Boyz 'N the Hood.

Within the context of increased flexibility, schools can change the way in which professionals interact and view students. If educators and others concerned with troubled and troubling youths believe that problems reside within the child, our current system of service delivery is adequate. If, however, we adopt a broader perspective on troubling behavior and believe that the problems some youths experience suggest a poor ecological fit or that institutions create problems when their organizational structures are insensitive to diverse groups of students, the current service delivery system must change.

\section{REFERENCES}

Affleck, J. Q., Madge, S., Adams, A., \& Lowenbraun, S. (1988). Integrated classroom versus resource model: Academic viability and effectiveness. Exceptional Children, 54, 339-348.

Algozzine, B., Ysseldyke, J. E., Kauffman, J. M., \& Landrum, T. J. (1991). Implications of school reform in the 1990s for teachers of students with behavior problems. Preventing School Failure, 35, 6-10.

Algozzine, B., \& Korinek, L. (1985). Where is special education for students with high prevalence handicaps going? Exceptional Children, $51,388-394$

“America 2000" choice plan could neglect special ed. (1991, June 19). Education of the Handicapped, p. 1.

Apter, S. J. (1982). Troubled children, troubled systems. New York: Pergamon. Axline, V. M. (1964). Dibs in search of self. New York: Ballantine Books.

Biklen, D. P. (1989). Redefining schools. In D. Biklen, D. L. Ferguson, \& A. Ford (Eds.), Schooling and disability. Chicago: National Society for the Study of Education.

Bogdan, R., \& Kugelmass, J. (1984). Case studies of mainstreaming: A symbolic interactionist approach to special schooling. In L. Barton \& $\mathrm{S}$. Tomlinson (Eds.), Special education and social interests (pp. 173-191). New York: Nichols.

Brady, M. P., McDougall, D., \& Dennis, H. F. (1989). The schools, the courts, and the integration of students with severe handicaps. Journal of Special Education, 23, 43-58.

Carlberg, C., \& Kavale, K. (1980). The efficacy of special versus regular class placement for exceptional children: A meta-analysis. Journal of Special Education, 14, 295-309.

Carnegie Forum on Education and the Economy. (1986). A nation prepared: Teachers for the 21st Century. Washington, DC: Carnegie Task Force on Teaching as a Profession.

Carnine, D. W., \& Kameenui, E. J. (1990). The general education initiative and children with special needs: A false dilemma in the face of true problems. Journal of Learning Disabilities, 23, 141-144. 
Carrier, J. G. (1990). Special education and the explanation of pupil performance. Disability, Handicap, \& Society, 5, 211-226.

Center for Policy Options in Special Education. (1992). Policy issues: Schoolsite restructuring. College Park: University of Maryland, College Park.

Cohen, D. L. (1989). Joining forces: State and communities experiment with child-services links. Education Week, 15.

Coleman, M. C. (1986). Behavior disorders: Theory and practice. Englewood Cliffs, NJ: Prentice-Hall.

Commission on Maine's Common Core of Learning. (1991). Maine's common core of learning: An investment in Maine's future. Augusta, ME: State Department of Education.

Council for Children with Behavioral Disorders. (1987). Position paper on identification of students with behavioral disorders. Behavioral Disorders, 13, 9-19.

Danielson, L. C. \& Bellamy, G. T. (1989). State variation in placement of children with handicaps in segregated environments. Exceptional Children, 55, 448-455.

Davis, W. E. (1989). The regular initiative debate: Its promises and problems. Exceptional Children, 55(5), 440-446.

Edgar, E., Levine, P., \& Maddox, M. (1986). Statewide follow-up studies of secondary special education students in transition (Working paper of the Networking and Evaluation Team). Seattle: CDMRC, University of Washington.

Elliot, D. H., \& Voss, H. L. (1974). Delinquency and dropout. Lexington, MA: Lexington Books.

Everhart, R. B. (1990). Disruptive behavior in organizational context. In P. E. Leone (Ed.), Understanding troubled and troubling youth (pp. 272-289). Newbury Park, CA: Sage.

Ford, J., Mongon, D., \& Whelan, M. (1982). Special education and social control: Invisible disasters. Boston: Routledge \& Kegan Paul.

Forness, S. R. (1988). Planning for the needs of children with serious emotional disturbance: The national special education and mental health coalition. Behavioral Disorders, 13, 127-133.

Forness, S. R. (1992). Legalism versus professionalism in diagnosing SED in the public schools. School Psychology Review, 21, 29-34.

Forness, S. R., Sinclair, E., \& Russell, M. J. (1984). Serving children with emotional and behavioral disorders: Implications for educational policy. American Journal of Orthopsychiatry, 54, 22-32.

Frank, A. R., Sitlington, P. L., \& Carson, R. (1991). Transition of adolescents with behavioral disorders-Is it successful? Behavioral Disorders, 16, 180-191.

Frey, W. (1991). Outcome indicators for special education: A model for studying the expected outcomes of education for students with disabilities. East Lansing, MI: Center for Quality Special Education.

Fuchs, D., \& Fuchs, L. S. (1988). An evaluation of the adaptive learning environments model. Exceptional Children, 55(3), 115-127.

Fuhrman, S., \& Elmore, R. (1990). Understanding local control in the wake of state education reform. Educational Evaluation and Policy Analysis, 12, 82-96.

Gartner, A., \& Lipsky, D. K. (1989). The yoke of special education: How to break it. Rochester, NY: National Center on Education and the Economy.

Goodlad, J. (1984). A place called school: Prospects for the future. New York: McGraw-Hill.

Graden, J. L., Casey, A., \& Bonstrom, O. (1985). Implementing a prereferral intervention system: Part II. The data. Exceptional Children, 51, 487-496.
Greenley, J. R., \& Robitschek, C. G. (1991). Evaluation of a comprehensive program for youth with severe emotional disorders: An analysis of family experiences and satisfaction. American Journal of Orthopsychiatry, 61, 292-297.

Grosenick, J. K. (1989). School services for behaviorally disordered students: A national perspective. In R. B. Rutherford \& S. A. DiGangi (Eds.), Severe Behavior Disorders (Monograph 12, pp. 11-20). Reston, VA: Council for Children with Behavior Disorders.

Grosenick, J. K., George, M. P., \& George, N. L. (1987). A profile of school programs for the behaviorally disordered: Twenty years after Morse, Cutler, and Fink. Behavioral Disorders, 12, 159-168.

Grosenick, J. K., \& Huntze, S. L. (1980). National needs analysis in behavior disorders: Adolescent behavior disorders. Columbia, MO: University of Missouri-Columbia.

Hasazi, S., Gordon, L., \& Roe, C. (1985). Factors associated with the employment status of handicapped youth exiting high school from 1979-1983. Exceptional Children, 51(6), 455-469.

Hehir, T., Stariha, W. E., \& Walberg, H. (1991). Promoting least restrictive environment in Chicago. Unpublished manuscript. Thomas Hehir, Associate Superintendent, Department of Special Education and Pupil Support Services, Chicago Public Schools, 1819 W. Pershing Rd., Chicago, IL 60609.

Hellman, D. A., \& Beaton, S. (1986). The pattern of violence in urban public schools: The influence of school and community. Journal of Research in Crime and Delinquency, 23, 102-127.

Hewett, F. M., \& Forness, S. R. (1977). Education of exceptional learners (2nd ed.). Boston: Allyn \& Bacon.

Hirschi, T. (1969). Causes of delinquency. Berkeley: University of California Press.

Hornbeck, D. W., \& Lehman, S. (1991). Success for each student: A plan to permanently eliminate the special education backlog while improving educational outcomes for all children in New York City. New York: Board of Education of the City of New York.

Kauffman, J. M. (1989a). Characteristics of children's behavior disorders. Columbus, $\mathrm{OH}$ : Merrill.

Kauffman, J. M. (1989b). The regular education initiative as Reagan-Bush education policy: A trickle-down theory of education of the hard to teach. Journal of Special Education, 23(3), 256-278.

Kauffman, J. M., Cullinan, D., \& Epstein, M. H. (1987). Characteristics of students placed in special programs for the seriously emotionally disturbed. Behavioral Disorders, 12, 175-183.

Kauffman, J. M., Gerber, M. M., \& Semmel, M. I. (1988). Arguable assumptions underlying the regular education initiative. Journal of Learning Disabilities, 21(1), 6-11.

Kentucky Department of Education. (1991). Measuring up!: Kentucky's new performance-based student assessment program. Frankfurt: Author.

Knight, M. R., Meyers, H. W., Paolucci-Whitcomb, P., Hasazi, S. E., \& Nevin, A. (1981). A four-year evaluation of consulting teacher services. Behavioral Disorders, 6, 92-100.

Knitzer, J. (1982). Unclaimed children: The failure of public responsibility health services. Washington, DC: Children's Defense Fund.

Knitzer, J., Steinberg, Z., \& Fleisch, B. (1990). At the schoolhouse door: An examination of programs and policies for children with behavioral and emotional problems. New York: Bank Street College of Education.

Kohlberg, L., \& Mayer, R. (1972). Development as the aim of education. Harvard Educational Review, 42, 449-496. 
Leinhardt, G., \& Pallay, A. (1982). Restrictive educational settings: Exile or haven? Review of Educational Research, 52, 557-578.

Leone, P. E. (1989). Beyond fixing bad behavior and bad boys: Multiple perspectives on education and treatment of troubled and troubling youth. In R. B. Rutherford and S. A. DiGangi (Eds.), Severe behavior disorders monograph, 12, 1-10. Reston, VA: Council for Children with Behavior Disorders.

Leone, P. E. (Ed.). (1990). Understanding troubled and troubling youth. Newbury Park, CA: Sage.

Levin, H. M. (1990). At-risk students in a yuppie age. Educational Policy, 4, 283-295.

Maag, J. W., \& Howell, K. (1992). Special education and the exclusion of socially maladjusted youth: A cultural organizational perspective. Remedial and Special Education, 13, 47-54.

McLaughlin, M. J., \& Owings, M. F. (in press). Use of extant data bases to examine the implementation of the Individuals with Disabilities Education Act. Exceptional Children.

Melton, G. B. (No date). Service models in child and adolescent mental health: What works for whom? (Tech. Rep.). Lincoln: University of Nebraska-Lincoln.

Morse, W. C., Cutler, R. L., \& Fink, A. H. (1964). Public school classes for the emotionally handicapped: A research analysis. Washington, DC: Council for Exceptional Children.

National Center on Educational Outcomes. (1991). Assessing educational outcomes: State activity and literature integration. Minneapolis: University of Minnesota.

National Coalition of Advocates for Students. (1985). Barriers to excellence: Our children at risk. Boston: Author.

Neel, R. S., Meadows, N., Levine, P., \& Edgar, E. B. (1988). What happens after special eciucation: A statewide follow-up study of secondary students who have behavioral disorders. Behavioral Disorders, 13, 209-216.

Nelson, C. M., \& Pearson, C. A. (1991). Integrating services for children and youth with emotional and behavioral disorders. Reston, VA: Council for Exceptional Children.

Nelson, C. M., \& Rutherford, R. B. (1990). Troubled youth in the public schools: Emotionally disturbed or socially maladjusted? In P. E. Leone (Ed.), Understanding troubled and troubling youth (pp. 38-60). Newbury Park, CA: Sage.

Nicolaides, S. (Producer), \& Singleton, J. (Director). (1991). Boyz 'N the Hood [film]. Burbank, CA: Columbia.

Northwest Regional Educational Laboratory. (1990). Effective schooling practices: A research synthesis 1990 update. Portland, OR: Author.

Office for Civil Rights. (1978-79). Directory of elementary and secondary school districts and schools in selected school districts. Washington, DC: U. S. Department of Education.

Polsgrove, L., \& McNeil, M. (1989). The consultation process: Research and practice. Remedial \& Special Education, 10(1), 6-13, 20.

Rhodes, W. C., \& Tracy, M. (1972). A study of child variance (Vol. 1). Ann Arbor: University of Michigan Press.

Rosenfield, S. (1992). Developing school-based consultation teams: A design for organizational change. School Psychology Quarterly, 7, $24-46$.

Rubin, T. I. (1962). Jordi, Lisa, and David. New York: Random House.

Sailor, W. (1991). Special education in the restructured school. Remedial \& Special Education, 12(6), 8-22.

Sapon-Shevin, M. (1987). The national education reports and special education: Implications for students. Exceptional Children, 53, 300-306.
Schaffner, C. B., \& Buswell, B. E. (1991). Opening doors: Strategies for including all students in regular education. Colorado Springs: PEAK Parent Center.

Shepard, L. A. (1987). The new push for excellence: Widening the schism between regular and special education. Exceptional Children, 53, 327-329.

Sizer, T. (1984). Horace's compromise: The dilemma of the American high school. Boston: Houghton-Mifflin.

Skrtic, T. M. (1991). The special education paradox: Equity as the way to excellence. Harvard Educational Review, 61(2), 148-206.

Smith, R. C. (1988). America's shame, America's hope: Twelve million youth at risk. Chapel Hill, NC: MDC, Inc. (ERIC Document Reproduction Service No. ED 301620)

Special Study Panel on Education Indicators. (1991). Education counts: An indicator system to monitor the nation's educational health. Washington, DC: National Center for Education Statistics.

Stainback, S., \& Stainback, W. (1984). A rationale for the merger of special and regular education. Exceptional Children, 51(2), 102-111.

Stainback, S., \& Stainback, W. (1989). Integration of students with mild and moderate handicaps. In D. K. Lipsky \& A. Gartner (Eds.), Beyond separate education: Quality education for all (pp. 41-52). Baltimore: Paul H. Brookes.

Thousand, J. S., \& Villa, R. A. (1989). Enhancing success in heterogeneous schools. In S. Stainback, W. Stainback, \& M. Forest (Eds.), Educating all students in the mainstream of regular education. Baltimore: Paul H. Brookes.

Toch, T. (1991). In the name of excellence: The struggle to reform the nation's schools. Paper presented at the 1991 American Educational Research Association Annual Meeting, Chicago.

Tomlinson, S. (1982). A sociology of special education. London: Routledge \& Kegan Paul.

Tropea, J. L. (1987). Bureaucratic order and special children: Urban schools, 1890s-1940s. History of Education Quarterly, 27, 29-56.

U. S. Department of Education (1991a). America 2000: An Education Strategy (Sourcebook). Washington, DC: Government Printing Office. (1991-296-149/40545)

U. S. Department of Education (1991b). Thirteenth annual report to congress on the implementation of the Individuals with Disabilities Education Act. Washington, DC: Author.

Valdes, K. A., Williamson, C. L., \& Wagner, M. M. (1990). The National Longitudinal Study of Special Education Students statistical almanac: Youth categorized as emotionally disturbed. Menlo Park, CA: SRI International.

Wagner, M. (1991). The transition experience of youths with disabilities: A report from the National Longitudinal Transition Study. Menlo Park, CA: SRI International.

William T. Grant Foundation Commission on Work, Family, and Citizenship. (1988). The forgotten half: Non-college youth in America. Washington, DC: Author.

Young, T. M. (1990). Therapeutic case advocacy: A model for interagency collaboration in serving emotionally disturbed children and their families. American Journal of Orthopsychiatry, 60, 118-124. 


\section{NEW BOOK FOR EDUCATORS} AND OTHER PROFESSIONALS BY LOVE PUBLISHING

Family Systems within Educational Contexts: Understanding Students with Special Needs by Rosemary Lambie and Debbie Daniels-Mohring is now available for purchase or review. This comprehensive text probes both the theories and practical applications of working with the whole family, not just the child, in getting struggling students back on track. The focus is on the student with special needs, with specific examples and case studies demonstrating the effectiveness of this approach. The authors also discuss life-cycle stages and environmental factors, such as divorce, relocation, poverty, addictions, and illnesses, that can affect a child's performance in school. They delve into the benefits of team approaches and how to overcome the barriers of working with families. Extensive appendices direct readers to other resources and further study.

9204/ISBN 0-89108-223-9/paperback/\$29.95

\section{PERMISSIONS AND COPYRIGHT}

All rights are reserved. No part of this publication may be reproduced, photocopied, faxed, stored in a retrieval system, or transmitted, in any form or by any means, electronic, mechanical, recording or otherwise, without the prior written permission of the publisher.
Back issues are available for sale. Reproduction requires permission and payment of fees. It is illegal and a violation of Federal copyright law to reproduce this publication without permission. Direct all inquiries to the permissions editor. 